\title{
Sexual partnerships of people living with the Human Immunodeficiency Virus*
}

\author{
Parcerias sexuais de pessoas vivendo com o Vírus da Imunodeficiência Humana
}

Layze Braz de Oliveira ${ }^{1}$, Matheus Costa Brandão Matos ${ }^{2}$, Giselle Juliana de Jesus ${ }^{1}$, Renata Karina Reis ${ }^{1}$, Elucir Gir ${ }^{1}$, Telma Maria Evangelista de Araújo ${ }^{2}$

Objective: to characterize the sexual partnerships established by people living with the Human Immunodeficiency Virus. Methods: an epidemiological study carried out with 173 participants in a medical assistance service specialized in the treatment of people with Human Immunodeficiency Virus. Data were collected through an individual interview with a specific questionnaire for the study. Pearson's Chi-square test was used to analyze the data. Results: the majority of the participants were male, young adults (54/30.9\%), single (94/53.7\%), complete high school $(72 / 41.1 \%)$ and sexually infected $(150 / 85.7 \%)$. The variables gender $(\mathrm{p}<0.001)$, marital status $(\mathrm{p}<0.001)$, living with partner $(\mathrm{p}<0.001)$, exposure form $(\mathrm{p}=0.040)$ and partner serology $(\mathrm{p}<0.001)$ showed statistical difference. Conclusion: people with this infection establish different forms of sexual partnerships, which were influenced by sex, marital status, living with the partner, form of exposure and serology of the partner.

Descriptors: HIV; Acquired Immunodeficiency Syndrome; Patient Care; Sexual Behavior.

Objetivo: caracterizar as parcerias sexuais estabelecidas por pessoas vivendo com o Vírus da Imunodeficiência Humana. Métodos: estudo epidemiológico realizado com 173 participantes em um serviço de assistência médica especializada no tratamento de pessoas com o Vírus da Imunodeficiência Humana. Os dados foram coletados por meio de entrevista individual com questionário específico para o estudo. Para análise dos dados foram utilizados os testes Qui-quadrado de Pearson. Resultados: a maioria dos participantes era do sexo masculino, adultos-jovens $(54 / 30,9 \%)$, solteiros $(94 / 53,7 \%)$, com ensino médio completo $(72 / 41,1 \%)$ e infectados por relação sexual $(150 / 85,7 \%)$. As variáveis sexo $(\mathrm{p}<0,001)$, estado civil $(\mathrm{p}<0,001)$, morar com parceiro ( $\mathrm{p}<0,001)$, forma de exposição $(p=0,040)$ e sorologia do parceiro $(p<0,001)$ mostraram diferença estatística. Conclusão: as pessoas vivendo com essa infecção estabelecem diferentes formas de parcerias sexuais, as quais foram influenciadas pelo sexo, estado civil, morar com o parceiro, forma de exposição e sorologia do parceiro.

Descritores: HIV; Síndrome de Imunodeficiência Adquirida; Assistência ao Paciente; Comportamento Sexual.

\footnotetext{
*From the dissertation "Estratégias de gerenciamento de risco da transmissão sexual do HIV e outras Infecções Sexualmente Transmissíveis entre pessoas vivendo com o HIV/aids", Universidade de São Paulo, Escola de Enfermagem de Ribeirão Preto, 2016.

${ }^{1}$ Universidade de São Paulo, Escola de Enfermagem de Ribeirão Preto. Ribeirão Preto, SP, Brazil.

${ }^{2}$ Universidade Federal do Piauí. Teresina, PI, Brazil. 


\section{Introduction}

There are approximately 38.8 million people living with Human Immunodeficiency Virus/Acquired Immunodeficiency Syndrome (HIV/AIDS) in the world $^{(1)}$, of which 798,366 live in Brazil. Of these, only about 450,000 used antiretroviral therapy ${ }^{(2)}$.

Nevertheless, the access to antiretroviral medication, the expansion of the diagnosis offer and the adhesion to the drug therapy provided changes in the patterns of this infection, turning from the profile of a fatal and incurable disease to gradually acquire chronicity characteristics ${ }^{(3)}$. This scenario leads to the emergence of conjugal relationships between people living with HIV/AIDS in which both are infected by the virus, called serum concordant, or in which only one is infected, serum discordant couples ${ }^{(4)}$.

One of the major problems faced by serum discordant couples is the risk of HIV transmission, especially among stable partnerships. A number of factors influence the risk of transmission in these relationships, especially sexual behavior, viral load and the presence of sexually transmitted infections ${ }^{(5)}$.

In these cases, the literature points out that the annual risk of transmission between serum discordant partners can be reduced if condom use is consistent. In addition, prevention strategies combined with the use of antiretroviral drugs are also listed as an important tool for prevention, since their efficacy decreases viral load in blood plasma, allowing a reduction in the sexual transmission of HIV among couples ${ }^{(6)}$.

Despite all these advances in relation to HIV infection, establishing a sexual partnership, be it fixed or casual, to many couples living in the context of HIV may be a barrier, because the lack of knowledge about transmission strategies, stigma and discrimination still overlap these relationships ${ }^{(6)}$.

Understanding how the configurations of sexual partnerships influence the profile of patients living with HIV infection is important, since it provides subsidy for the provision of specialized services in a holistic way contemplating, above all, the care of partners of people living with HIV, adding new scientific knowledge and subsidizing the planning of health promotion actions.

Considering the limited literature on this subject in the Brazilian scenario, it is expected that the study may subsidize the formulation and expansion of integrative strategies to assist this clientele in an integral way. Therefore, in order to reach an approximation to the intended object of study, the following question was asked: Does the type of sexual partnership influence the sociodemographic and clinical variables of patients living with HIV/AIDS?

In this perspective, the objective of the study was to characterize the sexual partnerships established by people living with the Human Immunodeficiency Virus.

\section{Methods}

Epidemiological study, developed in a Specialized Assistance Service of an Integrated Health Center in the State of Piauí, a region of northeastern Brazil, developed from November 2016 to March 2017. The unit has infrastructure for outpatient care of several specialties and has a team composed of three infectologists, two nurses and two nursing technicians. From 1980 to the end of 2015, 216 patients with viral hepatitis and 715 with HIV / AIDS were treated ${ }^{(7)}$.

The population of this study was composed of 715 people attended in this specialized care service with a sample of 173 patients. The inclusion criteria of the study were: subjects aged $\geq 18$ years; who was in a fixed or casual relationship in the last 30 days and with HIV serological test result. Exclusion criteria were: being pregnant and deprived of liberty, due to the inherent specificities of the clinical management of these populations and the organization of the local health care network; and those who gained access to antiretroviral drugs through the program, but with follow-up in private service.

Recruitment of the participants occurred before or after the appointment with an infectologist, 
scheduled or not. Subsequently, the interview took place in a private location, using a direct, individual approach, capturing the totality of eligible subjects, applying a questionnaire for sociodemographic, clinical evaluation and characteristics of participants' sexual partners such as gender, age, marital status, schooling, living with partner, exposure category, exposure form, partner serology, comorbidities, T-CD4 + count and diagnosis time.

Descriptive analyzes were performed using univariate and bivariate tests for the variables of interest. The data were processed with the help of the Statistical Package for Social Sciences Software version 20.0. The variables were analyzed with the chi-square test, was adopted $\mathrm{p}<0.05$ as level of significance.

The study complied with the formal requirements contained in national and international standards for research involving human beings.

\section{Results}

The sex partnerships were predominantly male 133 (76.9\%), aged between 30 and 39 years (38.9\%), 94 (53.7\%) were single and 100 (57.1\%) were dark-skinned. As for schooling, 50 (28.6\%) completed elementary education and 72 (41.1\%) completed secondary education. Regarding the financial situation, $116(66.3 \%)$ reported receiving up to three minimum wages.

Regarding sexual partnerships, 117 (67.6\%) had a fixed partnership, 91 (52.6\%) did not live with the partner and $150(86.7 \%)$ had contact with HIV through unprotected sexual intercourse. According to the form of exposure, $75(42.9 \%)$ reported having been infected in a heterosexual relationship, 70 $(40.0 \%)$ in a homosexual relationship and 22 (12.6\%) did not know how the exposure occurred. Regarding the serology of the partner, the most likely to be exposed to the risk of HIV infection were: 73 (42.2\%) were serum discordant and 54 (31.2\%) were not able to inform the serology of the partner.

The type of sexual partnership was influenced

by the variables gender $(\mathrm{p}<0.001)$, marital status ( $\mathrm{p}$ $<0.001)$, living with partner $(\mathrm{p}<0.001)$, exposure form $(p=0.040)$ and partner serology $(p<0.001)$ (Table 1$)$.

Table 1 - Distribution of types of sexual partnerships of people living with HIV/AIDS associated with socio-demographic and clinical characteristics

\begin{tabular}{|c|c|c|c|}
\hline \multirow{3}{*}{ Variables } & \multicolumn{2}{|c|}{ Sexual partnerships } & \multirow{3}{*}{$\mathbf{p}^{*}$} \\
\hline & Fixed & Casual & \\
\hline & n (\%) & n (\%) & \\
\hline \multicolumn{4}{|l|}{ Gender } \\
\hline Female & $35(7.5)$ & $5(12.5)$ & \multirow[t]{2}{*}{$<0.001$} \\
\hline Male & $83(61.7)$ & $50(38.3)$ & \\
\hline \multicolumn{4}{|l|}{ Age (years) } \\
\hline $20-29$ & $32(57.4)$ & $22(42.6)$ & \multirow{5}{*}{0.230} \\
\hline $30-39$ & $48(70.6)$ & $20(29.4)$ & \\
\hline $40-49$ & $18(66.7)$ & $9(33.3)$ & \\
\hline $50-59$ & $16(84.2)$ & $3(15.8)$ & \\
\hline$\geq 60$ & $4(80.0)$ & $1(20.0)$ & \\
\hline \multicolumn{4}{|l|}{ Schooling } \\
\hline No schooling & $2(50.0)$ & $2(50.0)$ & \multirow{5}{*}{0.151} \\
\hline Complete elementary school & $37(74.0)$ & $13(26.0)$ & \\
\hline Complete high school & $53(72.2)$ & $19(27.8)$ & \\
\hline Complete College & $23(53.5)$ & $20(46.5)$ & \\
\hline Complete post graduation & $3(75.0)$ & $1(25.0)$ & \\
\hline \multicolumn{4}{|l|}{ Marital status } \\
\hline Single & $47(50.0)$ & $47(50.0)$ & \multirow{4}{*}{$<0.001$} \\
\hline Married / Stable union & $69(89.6)$ & $8(10.4)$ & \\
\hline Separate / Divorced & $1(100.0)$ & - & \\
\hline Widower & - & $1(100.0)$ & \\
\hline \multicolumn{4}{|l|}{ Living with partner } \\
\hline Yes & $72(87.8)$ & $10(12.2)$ & \multirow{2}{*}{$<0.001$} \\
\hline No & $45(49.5)$ & $46(50.5)$ & \\
\hline \multicolumn{4}{|l|}{ Category of exposition } \\
\hline Blood & - & $1(100.0)$ & \multirow{3}{*}{0.210} \\
\hline Sexual & $100(66.7)$ & $50(33.3)$ & \\
\hline Do not know & $17(77.3)$ & $5(22.7)$ & \\
\hline \multicolumn{4}{|l|}{ Form of exposure } \\
\hline Heterossexual & $57(76.0)$ & $18(24.0)$ & \multirow{5}{*}{$<0.001$} \\
\hline Homossexual & $41(58.6)$ & $29(41.4)$ & \\
\hline Bissexual & $1(25.0)$ & $3(75.0)$ & \\
\hline Transfusion & $1(50.0)$ & $1(50.0)$ & \\
\hline Do not know & $17(77.3)$ & $5(22.7)$ & \\
\hline \multicolumn{4}{|l|}{ Partner Serology } \\
\hline Discordant & $62(84.9)$ & $11(15.1)$ & \multirow{3}{*}{$<0.001$} \\
\hline Concordant & $43(93.5)$ & $3(6.5)$ & \\
\hline Unknown & $12(22.2)$ & $42(77.8)$ & \\
\hline \multicolumn{4}{|l|}{ Comorbidities } \\
\hline Yes & $34(79.1)$ & $9(20.9)$ & \multirow[t]{2}{*}{0.070} \\
\hline No & $83(63.8)$ & $47(36.2)$ & \\
\hline T-CD4 Count (cel / mm3) & & & \\
\hline Up until 200 & $5(45.5)$ & $6(54.5)$ & חم? ת \\
\hline 201 to 499 & $27(65.9)$ & $14(34.1)$ & 0.200 \\
\hline$>500$ & $86(71.1)$ & 35 (28.9) & \\
\hline Diagnostic time (years) & & & \\
\hline Up until 2- & $54(65.1)$ & $29(34.9)$ & \\
\hline 3 to 5 & $39(69.6)$ & $17(30.3)$ & 0.570 \\
\hline 6 to 10 & $18(72.0)$ & $7(28.0)$ & \\
\hline$>11$ & $6(66.7)$ & $3(33.3)$ & \\
\hline
\end{tabular}


Regarding the clinical aspects related to HIV, 121 (69.1\%) had T-CD4 higher than $500 \mathrm{cel} / \mathrm{mm}^{3}$ and $11(6.3 \%)$ less than $200 \mathrm{cel} / \mathrm{mm}^{3}$, moreover 130 (74.3\%) did not present comorbidities. The time to diagnosis of HIV/AIDS ranged from less than two to 22 years.

\section{Discussion}

The study presented as a limitation the cross-sectional design that did not allow establishing causal relationships and patient follow-up. In addition, their findings cover the characterization of the profile only of patients with HIV who establish sexual partnership attended in a state of northeastern Brazil.

In the analysis of the data regarding the gender of the participants of this study, it was verified the predominance of males, which reinforces the importance of reaching adult males and young people so that specific interventions and care can be developed.

In Brazil, the forms of expression of sexuality are still strictly governed by gender issues, with women being the most impaired in these unequal relationships. In such a way that authors point out that many women are infected by their fixed partner, since the man is still the main responsible for determining what form of prevention will be used, which reinforces the need for sexual health education strategy for these men, whether they are in straight or homosexual relationships, fixed or casual ${ }^{(5)}$.

The literature indicates a strong relationship between the female sex and the regret after the knowledge of the serological status, which can make it difficult to establish sexual partnerships. The main factors for this are rejections and negative reactions after disclosure, possibly leading to repudiation, housing problems, separation of children and even violence ${ }^{(8)}$.

The establishment of sexual partnerships between young adults (30 to 39 years old) with incomes of up to three salaries and basic and full schooling corroborates a study carried out with couples living in the context of HIV/AIDS recruited in 14 European countries $^{(9)}$. There was a predominance of the dark skinned ethnic group, which can be explained by the predominance of this ethnic group over all the others in Brazil, a result of the strong miscegenation ${ }^{(8-9)}$.

Regarding the clinical condition, the majority of the patients presented a T-CD4 count above 500, diagnosed less than two years old, and had no comorbidities. Monitoring of HIV-infected patients is based on measurements of HIV-1 plasma RNA (viral load) and T-CD4 + (CD4) cell counts in the blood. In this perspective CD4 count above $350 / \mathrm{mm} 3$ improves the efficacy of antiretroviral therapies by reducing HIV transmission especially among couples with distinct serology for HIV ${ }^{(10)}$.

Regarding the marital status, the majority of people living with HIV/AIDS are in a fixed partnership, married or stable union, living with the partner. The dimensions of sexual partnership are not well listed in the literature as an individual factor for HIV transmission. On the other hand, this type of relationship favors the inconsistent use of condoms and consequently increased vulnerability to HIV and other sexually transmitted infections ${ }^{(11)}$.

Most new HIV infections are established through sexual contact, occurring mostly in heterosexual partnerships in low and middle income regions. The study evidences a similar reality, however, it is important to note that a percentage of patients reported not knowing how they had contact with the virus, which in turn can mask the real situation of HIV exposure and further increase vulnerability, so that they cannot properly prevent themselves without understanding how they have been or can be infected ${ }^{(12)}$.

The use of combined strategies, characterized by the use of more than one preventive strategy, is a synergistic action that reduces the risk of HIV transmission among sexual partners. The first measure advocated by the World Health Organization is the consistent use of condoms. In addition, the literature demonstrates other efficient and effective measures such as early drug therapy and the use of post-exposure prophylaxis ${ }^{(13)}$. 
Although not yet being implemented in the Brazilian context the drug used during sexual pre-exposure, marketed in the United States as Truvada $\AA$, has been recommended mainly for serum discordant couples, as a positive perspective in the prevention of this infection, and refers to the availability of therapy before possible exposure to HIV in unprotected sexual intercourse $\mathrm{e}^{(14)}$. With proper use and correct adhesion the risk of HIV transmission decreases substantially.

Regarding the serology of the partner, the majority are serum discordant couples and a significant percentage is unaware of the serology of the partner. When it comes to sexual partnerships, there is concern about the aspects that involve HIV transmission, especially in the acute phase of infection in which the highest percentage of transmission occurs. In fixed sex partnerships, negotiating condom use is an obstacle for such couples, since the lack of condom use in many relationships is a sign of confidence ${ }^{(15-16)}$.

The disclosure of HIV serology to the sexual partner is being recognized as an important part in preventing this infection, especially by the possibility of partner support for adhesion to the clinical, medicated and emotional care to the infected person; in addition, the couple can still discuss the best strategy to be used ${ }^{(17)}$.

Viral suppression sustained through antiretroviral therapy greatly reduces the risk of sexual transmission of HIV, expanding the possibilities for prevention. It is estimated that the risk of HIV infection in serum discordant couples undergoing drug therapy through unprotected sexual contact is around 0.0001 to 0.014 per sex ${ }^{(18)}$.

Similarly, other variables were also listed in the literature as decisive in HIV transmission such as the impact of the infected person's age, type and frequency of sexual activity, circumcision, presence of other sexually transmitted infections, use of barrier contraception methods, host genetic background, presence of mutation in HIV co-receptors, variability in histocompatibility antigens, and killer cell immunoglobulin-like receptors ${ }^{(19)}$.

Despite the level of recent evidence that suppression of viral load considerably reduces the risk of HIV transmission, it is important to highlight the possibility of co-infections, especially in competing partnerships, which reinforces the importance of implementing a combined strategy. The presence of another sexually transmitted infection favors an increase in viral load, increasing the risk for the spread of this virus $^{(18)}$.

In this perspective, it is important to articulate an integrated health care network that provides holistic care to these patients, so as not to offer only the diagnosis and treatment offer, but also to approach the patient in an integral way, providing sustainable care, through the use of appropriate strategies. Despite the vast literature pointing to the increase in the formation of couples living with this infection, there is still a gap in the performance of the service, professional and user triad, which hinders the integral care of the user.

Specialized services in general are based on a bureaucratic dynamic that often does not meet the patients' bio psychosocial demands and is restricted to the care of the biological aspects of the disease, a fact observed in the case of people living with HIV/ AIDS treated in the service specialist assistance in this study.

In this perspective, the efficacy of this service should be linked to the recognition of the importance of couple care for counseling and multi professional interventions providing crucial information on HIV transmission and the new biomedical technologies available to these couples.

The results add new scientific knowledge about sexual partnerships of people living with HIV, subsidizing the planning of health promotion actions, especially in the northeastern region of the country, a region of Brazil that is still little studied by national and international literature. 


\section{Conclusion}

People living with this infection establish different forms of sexual partnerships, which were influenced by sex, marital status, living with partner, exposure form and partner's serology.

\section{Collaborations}

Oliveira LB and Reis RK contributed in the conception and design or analysis and interpretation of the data, in the writing of the article, in the relevant critical revision of the intellectual content and in the final approval of the version to be published. Matos MCB, Jesus GJ, Gir E and Araújo TME contributed in the final approval of the version to be published.

\section{References}

1. Wang H, Wolock TM, Cater A, Nquyen G, Kyu HH, Gakidou, et al. Estimates of global, regional, and national incidence, prevalence, and mortality of HIV, 1980-2015: the Global Burden of Disease Study 2015. Lancet HIV. 2016; 3(8):e361-e387. doi:http: / / dx.doi.org/10.1016/S23523018(16)30087-X

2. Ministério da Saúde (BR). Secretaria de Vigilância em Saúde. Departamento de DST, Aids e Hepatites Virais. Boletim epidemiológico HIV/Aids [Internet]. 2015 [citado 2017 maio 25]. Disponível em: http://www.aids.gov.br/pt-br/node/90

3. Almeida PD, Brito RCT, Araújo TME, Oliveira FBM, Sousa AFL, Araújo Filho ACA. Aids no Piauí: análise do perfil epidemiológico. Rev Enferm UFPE on line [Internet]. 2015 [citado 2017 maio 25]; 9(6):8660-4. Disponível em: http://www. revista.ufpe.br/revistaenfermagem/index.php/ revista/article/view/6927/pdf_8234

4. Tadesse M. Assessment of HIV discordance and associated risk factors among couples receiving HIV test in Dilla, Ethiopia. BMC Res Notes. 2014; 7(1):893-5. doi: http://dx.doi.org/10.1186/17560500-7-893
5. Tam VV, Cuong DD, Alfven T, Phuc HD, Chuc NTK, Hoa NP, et al. HIV serodiscordance among married HIV patients initiating antiretroviral therapy in northern Vietnam. AIDS Res Ther. 2016; 13(12):39. doi: http://dx.doi.org/10.1186/ s12981-016-0124-9

6. Vasquez AL, Errea RA, Hoces D, Echevarria JE, González-Lagos E, Gotuzzo E. Missed opportunities for HIV control: Gaps in HIV testing for partners of people living with HIV in Lima, Peru. PloS One. 2017; 12(8):e0181412. doi: https://doi. org/10.1371/journal.pone.0181412

7. Oliveira LB, Matos MCB, Costa CRB, Jesus GJ, Argolo JGM, Reis RK. Establishment of Partnerships in peoplelivingwithhiv/aids attended inaSpecialized center: experience report'. Sylwan. 2017 [cited 2017 May 25]; 162(7): 106-21. Available from: http://sylwan.ibles.org/syl/index.php/archive/ part/161/7/1/?currentVol=161\&currentissue=7

8. Dube BNR, Marshall, Tom P, Ryan RP. Predictors of human immunodeficiency virus (HIV) infection in primary care: a systematic review protocol. Syst Rev. 2016; 5(3):158-64. doi: http://dx.doi. org/10.1186/s13643-016-0333-2

9. Rodger AJ, Cambiano V, Bruun T, Vernazza P, Collins S, Lunzen J, et al. Sexual activity without condoms and risk of HIV transmission in serodifferent couples when the HIV-positive partner is using suppressive antiretroviral therapy. JAMA. 2016; 316(2):171-81. doi: http://dx.doi.org/10.1001/ jama.2016.5148

10. Oliveira LB, Queiroz AAFLN, Sousa ÁFL, Araújo TME, Moura MEB, Reis RK. Epidemiologia do HIV/Aids em estado do nordeste do Brasil: série histórica de 2007 a 2015. Evidentia. 2017. No prelo.

11. Henry E, Bernier A, Lazar F, Matamba G, Loukid M, Bonifaz C, et al. "Was it a mistake to tell others that you are infected with HIV?": factors associated with regret following HIV disclosure among people living with HIV in five countries (Mali, Morocco, Democratic Republic of the Congo, Ecuador and Romania). Results from a community-based research. AIDS Behav. 2015; 19(2):311-21. doi: http://dx.doi.org/10.1007/s10461-014-0976-8 
12. Dourado I, MacCarthy S, Reddy M, Calazans G, Gruskin S. Revisitando o uso do preservativo no Brasil. Rev Bras Epidemiol. 2015; 18(1):6388. doi: http://dx.doi.org/10.1590/18094503201500050006

13. Jenness SM, Goodreau SM, Morris M, Cassels S. Effectiveness of combination packages for HIV1 prevention in sub-Saharan Africa depends on partnership network structure: a mathematical modelling study. Sex Transm Infect. 2016; 92(8):619-24. doi: http://dx.doi.org/10.1136/ sextrans-2015-052476

14. Said AP, Seidl EMF. Sorodiscordância e prevenção do HIV: percepções de pessoas em relacionamentos estáveis e não estáveis. Interface. 2015; 19(54):467-78. doi: http://dx.doi. org/10.1590/1807-57622014.0120

15. Taylor SW. Psaros C. "Life-Steps" for PrEP adherence: demonstration of a CBT-Based Intervention to Increase Adherence to Preexposure Prophylaxis (PrEP) Medication Among SexualMinority Men at High Risk for HIV Acquisition. Cogn Behav Prat. 2017; 24(1):38-49. doi: http:// dx.doi.org/10.1016/j.cbpra.2016.02.004
16. Queiroz AAFLN, Sousa AFL. Fórum PrEP: um debate online sobre uso da "Profilaxia préexposição" no Brasil. Cad Saúde Pública. 2017; 33(11):e00112516. doi: http://dx.doi. org/10.1590/0102-311X00112516

17. Obiri-Yeboah, Amoako-Sakyi D, Baidoo L, AduOppong A, Rheinla"nder T. The 'Fears' of disclosing HIV status to sexual partners: a mixed methods study in a counseling setting in Ghana. AIDS Behav. 2016; 20(1):126-36. doi: http://dx.doi. org/10.1007/s10461-015-1022-1

18. Zwolińska K, Fleischer-Stępniewska K, Knysz B, Błachowicz 0, Piasecki E. Genetic diagnosis of seronegative (HIV-) partner of female patient with AIDS in the context of HIV transmission. HIV AIDS Rev. 2016; 15(2):97-100. doi: https://doi. org/10.1016/j.hivar.2016.03.005

19. Perry NS, Taylor SW, Elsesser S, Safren SA, O'Cleirigh C. The predominant relationship between sexual environment characteristics and HIV-serodiscordant condomless anal sex among HIV-positive men who have sex with men (MSM). AIDS Behav. 2016; 20(6):1228-35. doi: http:// dx.doi.org/10.1007/s10461-015-1202-z 